\title{
Binding of a Monoclonal Anti-DNA Autoantibody to Identical Protein(s) Present at the Surface of Several Human Cell Types Involved in Lupus Pathogenesis
}

\author{
Laurent Jacob, Marie-Annick Lety, Daniel Louvard, and Jean-François Bach \\ Inserm U25, Hôpital Necker, 161 Rue de Sèvres, 75015 Paris, France; Department of Internal Medicine, Hôpital Cochin, \\ 27 rue du Faubourg Saint Jacques, 75014 Paris, France; and Department of Molecular Biology, Membrane Biology Unit, \\ Institut Pasteur, 25 rue du Docteur Roux, 75015 Paris, France
}

\begin{abstract}
A monoclonal anti-DNA antibody PME77, spontaneously produced in autoimmune $B / W$ mice, has been found to recognize identical protein(s) present at the surface of several human cell types involved in the pathogenesis of systemic lupus erythematosus: glomeruli, platelets, erythrocytes, $T$ and $B$ cells, and neuronal tissue. Data indicate that protein(s) could represent a major stimulus or the target of anti-DNA autoimmunity and could account for tissue lesions observed in this disease.
\end{abstract}

\section{Introduction}

Most tissue lesions observed in murine and human systemic lupus erythematosus (SLE) ${ }^{1}$ are considered to be related to the presence of anti-double-stranded deoxyribonucleic acid (dsDNA) antibodies that are spontaneously produced in large amounts. These antibodies are believed to be deposited in the form of DNA-anti-DNA complexes in many organs (1). However, it is difficult to produce antibodies to dsDNA by deliberate immunization (2). We recently reported that a murine monoclonal anti-DNA antibody (mAb) PME77 recognizes polypeptides present at the surface of the human B lymphoblastoid cell line Raji (3). Three of them are abondant and easily removed from the cell surface. We show here that this $m A b$ reacts with five well-defined polypeptides at the surface of several cell types involved in the pathogenesis of SLE: glomeruli, platelets, erythrocytes, $T$ cells (studied in the form of a $T$ lymphoblastoid cell line CEM), and neuronal tissue. The antigenic determinant recognized by the PME77 mAb is thought to be present at the cell surface as evidenced by its disappearance after proteinase $\mathrm{K}$ treatment.

\section{Methods}

Mammalian cell types. The human lymphoblastoid B cell line (Raji) and the human lymphoblastoid T cell line (CEM) were obtained and

Received for publication 20 July 1984 and in revised form 26 September 1984

1. Abbreviations used in this paper: dsDNA, double-stranded deoxyribonucleic acid; mAb, monoclonal antibody; SLE, systemic lupus erythematosus.

J. Clin. Invest.

(c) The American Society for Clinical Investigation, Inc.

0021-9738/85/01/0315/03 $\$ 1.00$

Volume 75, January 1985, 315-317 maintained as previously described (4). Human erythrocytes were separated from mononuclear cells by centrifugation on Ficoll-Paque (Pharmacia, Inc., Piscataway, NJ) as described (5). Human platelets were provided by the blood bank of Necker Hospital, Paris, France.

Human glomeruli were isolated by Dr. L. H. Noel from Necker Hospital, according to a procedure based on the method described by Westberg and Michael (6). Normal kidney was perfused with Collins solution. The medulla was dissected away from the cortex and discarded. The cortex was then transferred to a 160-mesh stainless steel sieve. The tissue was forced through the sieve with moderate pressure using the bottom of a small flask and repeated washing with cold $0.85 \%$ sodium chloride solution, $0.5-1$ liter for one adult size kidney. The pressing was continued for about $10 \mathrm{~min}$ per application or for $1 \mathrm{~h}$ per kidney. Material remaining on the screen was discarded. The sieved suspension was then poured through a 60 -mesh sieve (pore size, $230 \mu \mathrm{m})$ to retain large tissue fragments, and finally through a 200 or 250 -mesh sieve (opening, 74 or $61 \mu \mathrm{m}$ ). The material retained on the fine sieve was then extensively washed with cold $0.85 \%$ sodium chloride, 1-2 liter per kidney, until nothing but glomeruli, and possibly some tubular fragments attached to glomeruli, could be seen by phase contrast microscopy. This material was washed into a beaker, transferred to $50-\mathrm{ml}$ plastic centrifuge tubes, and centrifuged at $1,080 \mathrm{~g}$ for 10 min. Finally, the sediment was washed four times in distilled water with centrifugation at $1,080 \mathrm{~g}$ at $4^{\circ} \mathrm{C}$ for $10 \mathrm{~min}$. During the entire procedure, the tissue was carefully kept on ice.

Other tissues were isolated from rat including liver, pancreas, large intestine, testicle, and ovary. Membrane of rat neuronal tissue was kindly provided by Mrs. Ariane Monron from Pasteur Institute, Paris, France, and mouse teratocarcinoma line F9 was provided by Dr. F. Jacob from Pasteur Institute (7).

Murine monoclonal antibodies (mAb). The hybridoma PME77 secreting anti-DNA antibody was obtained after fusion between a nonsecreting myeloma line $(\mathrm{P} 3 \times 63 \mathrm{Ag} 8.653)$ and (New Zealand Black $\times$ New Zealand White) F1 spleen cells. PME77 mAb was shown to be sharply specific for dsDNA (8).

Gel electrophoresis and immunoreplica analysis. Gel extracts were prepared following the procedure described by Garrels and Gibson (9). Cells were lysed at $4^{\circ} \mathrm{C}$ in a buffer containing $2 \mathrm{mM} \mathrm{CaCl}_{2}, 20 \mathrm{mM}$ Tris- $\mathrm{HCl}$, and $50 \mu \mathrm{g} / \mathrm{ml}$ staphylococcal nuclease (Boehringer Mannheim Biochemicals, Indianapolis, IN) adjusted at $\mathrm{pH} 8.8$ at a cellular protein concentration of $1-2 \mathrm{mg} / \mathrm{ml}$. Then 0.1 vol of $3 \%$ sodium dodecyl sulfate (SDS) $10 \% 2$-mercaptoethanol was added at $4^{\circ} \mathrm{C}$. The extract was treated with deoxyribonuclease and ribonuclease at $4^{\circ} \mathrm{C}(1 \mathrm{mg} / \mathrm{ml}$ of deoxyribonuclease I [Boehringer Mannheim Biochemicals] and 0.5 $\mathrm{mg} / \mathrm{ml}$ of ribonuclease $\mathrm{A}$ [Boehringer Mannheim Biochemicals] in $\mathbf{5 0}$ $\mathrm{mM} \mathrm{MgCl} 2,0.5 \mathrm{M}$ Tris- $\mathrm{HCl}, \mathrm{pH}$ 7.0). All steps were performed in the presence of $0.1 \mathrm{mM}$ phenylmethyl sulfonidefluoride and the mixture of proteases inhibitors described by Craig and Lancashire (10). Sodium dodecyl sulphate-polyacrylamide gel slab gels were run according to Laemmli (11). After electrophoresis, the immunoreplica technique was performed as described by Burnette (12), modified by Coudrier et al. (13). After electrotransfer of polypeptides, the nitrocellulose sheet was 
incubated with the supernatant of PME77 mAb secreting hydridoma for $90 \mathrm{~min}$ at room temperature. The antigen-PME77 mAb complexes were detected with the peroxidase technique. Molecular weight markers were phosphorylase b $(93,000)$, bovine serum albumin $(66,000)$, ovalbumin $(43,000)$, carbonic anhydrase $(30,000)$, trypsin inhibitor $(20,000)$, and lactalbumin $(14,000)$.

\section{Results}

PME77 anti-DNA MAb binds to identical polypeptides present at the surface of different cell types. We have previously reported that PME77 mAb with strict specificity for dsDNA recognizes polypeptides present at the surface of Raji cells (3). To determine whether the same polypeptides were recognized on cell types involved in the pathogenesis of SLE, immunoreplica analysis was used. Electrophoresis of polypeptides extracted from different cell types was performed. Polypeptides thus separated were transferred to the nitrocellulose sheet. The supernatant of PME77 mAb was then added and incubated. As shown in Fig. 1, five bands were detected at 14,000, 16,000, $17,000,33,000$, and 34,000 in glomeruli extract. These bands were strongly reduced when PME77 mAb was preincubated with $1 \mathrm{mg} / \mathrm{ml}$ DNA, and not seen when using a DNAunrelated $\mathrm{mAb}$ raised against a minor membrane protein of the golgi apparatus (14). To determine the cell surface accessibility of the antigenic determinant recognized by the PME77 $\mathrm{mAb}$ and to confirm its proteinic nature, a mild proteinase $\mathrm{K}$ treatment was applied to living cells as previously described in detail (3).
A proteinase $\mathrm{K}$ treatment rendered the cell unreactive to the PME77 mAb.

The same strategy was used to study the antigenic determinant recognized by the PME77 mAb on various cell types: platelets, erythrocytes, a $\mathrm{T}$ lymphoblastoid cell line CEM, neuronal tissue membrane, ovary, testicle, and teratocarcinoma line F9. The same five bands were detected in total cell extract, all sensitive to the proteinase $K$ treatment (Table I).

A strong reaction was observed with glomeruli, T lymphoblastoid cell line, and teratocarcinoma. A weaker reaction was found with erythrocytes (Fig. 1), platelets, neuronal tissue membrane, ovary, and testicle. No reaction was observed with other tissue such as liver (Fig. 1), large intestine, and pancreas (Table I). These results suggest that the five polypeptides are expressed at different levels in the various cell types involved in lupus pathogenesis.

\section{Discussion}

Anti-DNA antibodies are the predominant autoantibodies in murine and human SLE. If one considers, however, that such antibodies are exclusively directed against DNA, it seems difficult to explain the paradox between the frequency with which these antibodies are spontaneously produced in large amounts, and the difficulties met to elicit their production by deliberate immunization by nucleic acid preparation in nonautoimmune animals.

The recognition by anti-DNA mAb of phospholipids gave

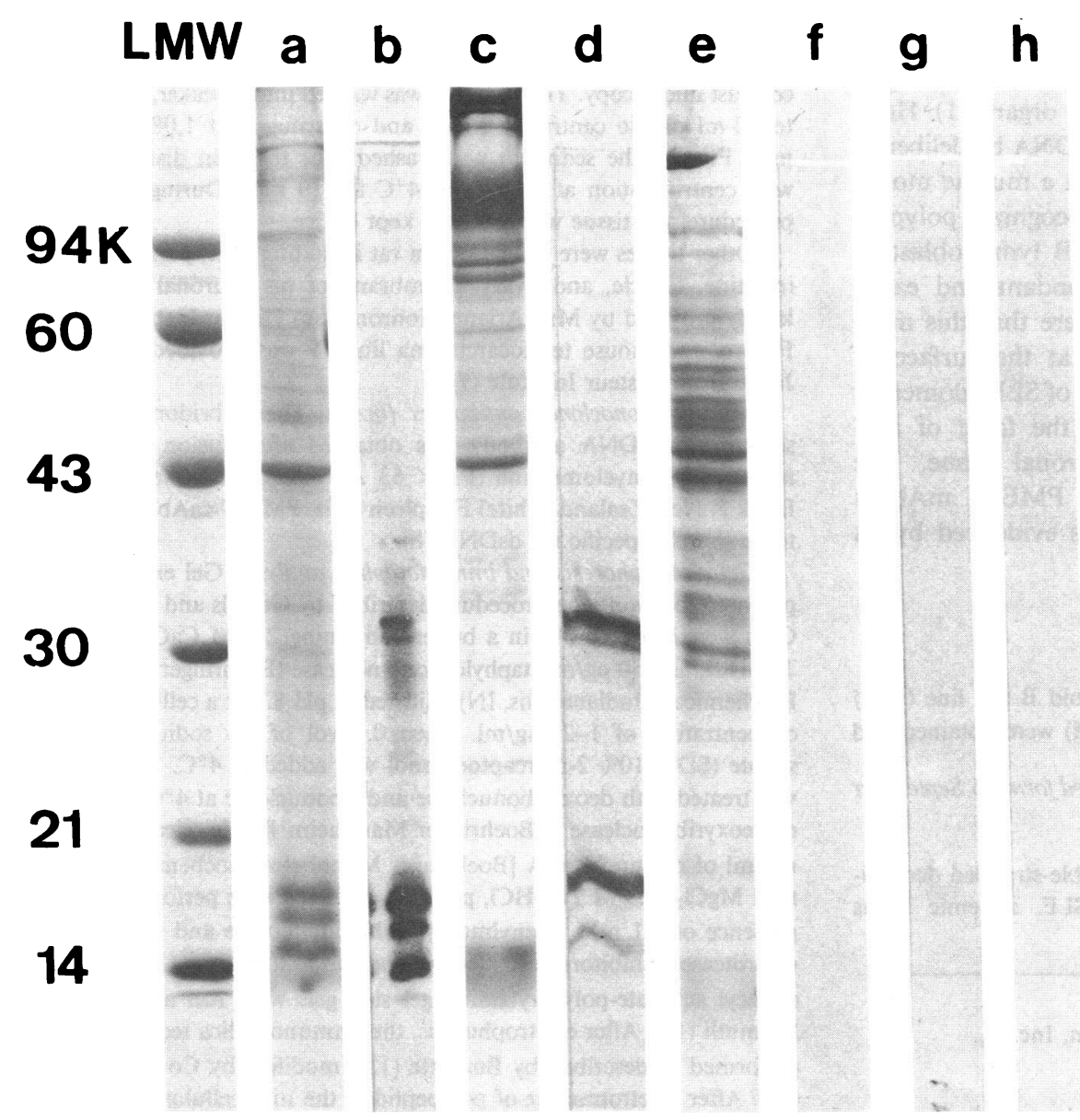

Figure 1. Electrophoretic protein pattern and specific immunoreplica analysis of human glomeruli extract, human erythrocyte extract, and rat liver extract. In each case, the gels were loaded with $20 \mu \mathrm{g}$ of glomeruli extract, $50 \mu \mathrm{g}$ of erythrocyte extract, and $50 \mu \mathrm{g}$ of liver extract. (a) glomeruli extract, total protein pattern; (b) glomeruli extract transfer to a nitrocellulose sheet and incubated with PME77 $\mathrm{mAb} ;(c)$ erythrocyte extract, total protein pattern; $(d)$ erythrocyte extract transfer to a nitrocellulose sheet and incubated with PME77 $\mathrm{mAb}$; $(e)$ liver extract, total protein pattern; $(f)$ liver extract transfer to a nitrocellulose sheet and incubated with PME77 mAb; $(g)$ control with PME77 mAb preincubated with DNA; $(h)$ control with anti-golgi mAb. The difference of the intensity of the reaction is only semi-quantitative, since cell extracts were analysed in separate experiments. However, these results indicate that different organs express variable amounts of polypeptides. 
Table I. Binding of PME77 mAb to Five

Polypeptides Present at the Surface of Different Cell Type Extracts Used at Different Concentrations

\begin{tabular}{llll}
\hline Cell type extracts & $\begin{array}{l}\text { Strong } \\
\text { reaction }\end{array}$ & $\begin{array}{l}\text { Weak } \\
\text { reaction }\end{array}$ & $\begin{array}{l}\text { No } \\
\text { reaction }\end{array}$ \\
\hline $\begin{array}{l}\text { Human platelets }(50 \mu \mathrm{g}) \\
\text { Human erythrocytes }(50 \mu \mathrm{g})\end{array}$ & + & \\
$\begin{array}{l}\text { Human glomeruli }(20 \mu \mathrm{g}) \\
\text { Human T lymphoblastoid cell }\end{array}$ & ++ & + & \\
$\quad$ line CEM $(20 \mu \mathrm{g})$ & ++ & & \\
Human B lymphoblastoid cell & & & \\
$\quad$ line Raji $(20 \mu \mathrm{g})$ & ++ & & - \\
Rat neuronal tissue & & + & - \\
$\quad$ membrane $(50 \mu \mathrm{g})$ & & + & - \\
Rat ovary $(50 \mu \mathrm{g})$ & & + & \\
Rat testicle $(50 \mu \mathrm{g})$ & & & \\
Rat liver $(50 \mu \mathrm{g})$ & & \\
Rat large intestine $(50 \mu \mathrm{g})$ & & \\
Rat pancreas $(50 \mu \mathrm{g})$ & & \\
Mouse teratocarcinoma cell & & \\
$\quad$ line F9 $(20 \mu \mathrm{g})$ & ++ & \\
\hline
\end{tabular}

the first hint of a possible triggering mechanism (15). Our recent report that $\mathrm{mAb}$ with strict specificity for dsDNA recognizes polypeptides at the surface of Raji cells (3) provides another possible clue. Here, we demonstrate that this $\mathrm{mAb}$ recognizes identical polypeptides on the surface of different human cell types involved in SLE: glomeruli, erythrocytes, platelets, $T$ cells (studied in the form of $T$ lymphoblastoid cell lines CEM), and neuronal tissue membrane. The high affinity of the anti-DNA mAb for these polypeptides might account for some of the autoantibody cross-reaction observed in SLE, such as that found between anti-neuronal, anti-erythrocytes, and anti-lymphocyte antibodies (16), or that described between anti-lymphocyte and anti-nuclear antibodies (17). These results open the possibility that the triggering antigen in SLE could be a protein cross-reacting with DNA, rather than DNA itself, accounting for the tissue lesions observed in this disease. This hypothesis would account for the low immunogenicity of nucleic acids outlined above.

The strong reaction observed with teratocarcinoma cell line suggests that the polypeptides in question are present at a high concentration in undifferentiated cell types that could have important implications for the establishment of selftolerance to the antigen(s) involved in human SLE in early stages of embryon immunologic development.

\section{Acknowledgments}

This work was supported by Institut National de la Santé et de la Recherche Médicale, grant 811850 to Dr. Jacob.

\section{References}

1. Dixon, F. J., A. G. Theophilopoulos, S. Izui, and I. J. MacConahey. 1980. Murine SLE: aetiology and pathogenesis. In Progress in Immunology. M. Fougereau, and J. Dausset, editors. Academic Press, Inc., New York. 959-995.

2. Stollar, D. B. 1973. Nucleic acid antigens. The Antigens, Vol. I. M. Sela, editor. Academic Press, Inc., New York. 1-84.

3. Jacob, L., F. Tron, J. F. Bach, and D. Louvard. 1984. A monoclonal anti-DNA antibody binds also to cell surface protein(s). Proc. Natl. Acad. Sci. USA. 81:3843-3845.

4. Tron, F., L. Jacob, and J. F. Bach. 1984. Binding of a murine monoclonal anti-DNA antibody to Raji cells: implications for the interpretation of the Raji cell assay for immune complexes. Eur. J. Immunol. 14:283-286.

5. Boyum, A. 1968. Isolation of monolayer cells and granulocytes from human blood. Scand. J. Clin. Lab. Invest. 21(Suppl. 97):77-89.

6. Westberg, N. G., and A. F. Michael. 1970. Human glomerular basement membrane: preparation and composition. Biochemistry. 9:3837-3846.

7. Jacob, F. 1978. The 1977 Leeuwenhoek lecture: Mouse teratocarcinoma and mouse embryo. Proc. R. Soc. Lond. B. Biol. Sci. 201: 249-270.

8. Jacob, L., and F. Tron. 1982. Monoclonal antideoxyribonucleic antibodies. I. Isotope and specificity studies. J. Immunol. 128:895898.

9. Garrels, J. I., and W. Gibson. 1976. Identification and characterization of multiple forms of actin. Cell. 9:793-805.

10. Craig, S. W., and C. L. Lancashire. 1980. Comparison of intestinal brush-border $95-\mathrm{KDalton}$ polypeptide and alpha-actinins. $J$. Cell Biol. 84:655-667.

11. Laemmli, U. K. 1970. Cleavage of structural proteins during the assembly of the head of bacteriophage. T4. Nature (Lond.) 227:680684.

12. Burnette, W. N. 1981. "Western blotting": electrophoretic transfer of proteins from sodium dodecyl sulfate-polyacrylamide gels to unmodified nitrocellulose and radiographic detection with antibody and radioiodinated protein A. Anal. Biochem. 112:195-203.

13. Coudrier, E., H. Reggio, and D. Louvard. 1983. Characterization of an integral membrane glycoprotein associated with the microfilaments of pig intestinal microvilli. Embo. J. 2:469-475.

14. Burke, B., G. Griffiths, H. Reggio, D. Louvard, and G. Warren. 1982. A monoclonal antibody against a $135-\mathrm{K}$ golgi membrane protein. EMBO. J. 12:1621-1628.

15. Lafer, E. M., J. Rauch, C. Andrzejewski, Jr., D. Mudd, B. Furie, R. S. Schwartz, and B. D. Stollar. 1981. Polyspecific monoclonal lupus antoantibodies reactive with both polynucleotides and phospholipids. J. Exp. Med. 153:897-909.

16. Bresnihan, B., M. Oliver, B. Williams, and G. R. V. Hughes. 1979. An antineuronal antibody cross-reacting with erythrocytes and lymphocytes in systemic lupus erythematosus. Arthritis Rheum. 22:313320.

17. Searles, R. P., R. P. Messnere, and A. D. Bankhurst. 1979. Cross-reactivity of anti-lymphocyte and anti-nuclear antibodies in systemic lupus erythematosus. Clin. Immunol. Immunopathol. 14:292299. 